ScIDice

\section{Prevalence of Oral Submucous Fibrosis (Osmf) Among Patients Visiting an Institutional Hospital Set Up}

Research Article

Geethika B ${ }^{1}$, Manjari Chaudhary ${ }^{*}$

${ }^{1}$ Saveetha Dental College and Hospitals, Saveetha Institute of Medical and Technical Sciences, Saveetha University, Chennai 600077, Tamil Nadu, India. ${ }^{2}$ Senior Lecturer, Department of Oral Medicine and Radiology, Saveetha Dental College and Hospitals, Saveetha Institute of Medical and Technical Sciences, Saveetha University, Chennai 600077, Tamil Nadu, India.

Abstract

Oral Submucous fibrosis (OSMF) occurs in young adults, who are in the habit of chewing tobacco mixed with areca nut and its various commercially available preparations. The disease results in progressive inability to open the mouth due to the submucosal fibrosis initiated by chronic inflammation affecting mainly oral mucosa. Oral Submucous Fibrosis (OSMF) is a disease that frequently occurs among the Indian population. The present study aims to evaluate the prevalence of OSMF among the population visiting an institutional hospital set up. This retrospective study was conducted among the patients visiting the Oral Medicine and Radiology (OMR) department of a private dental college. The data was collected by reviewing the case sheets of the patients diagnosed with OSMF. The collected data was statistically analysed using IBM SPSS Software (20.0). Within the limits of the study, it can be concluded that OSMF was more prevalent among males. It can be seen that the Grade- I, III, IV of OSMF are the most prevalent among males and Grade II is more prevalent among females. The association between gender and OSMF is statistically significant ( $p$-value: $0.016<0.05$ ). It is the most prevalent among the age group of 20-29 years and 40-49 years; Grade I OSMF was the most prevalent among all the age groups. This association between age and the prevalence of different grades of OSMF shows a high statistical significance ( $p$-value: $0.008<0.01$ ).

Keywords: Age; Chennai; Male; OSMF; Grading; Prevalence.

\section{Introduction}

Oral submucous fibrosis is a chronic insidious disease affecting any part of the oral cavity and sometimes the pharynx [1]. It causes trismus and difficulty to eat due to its association with juxta epithelial inflammatory reaction. This is followed by fibroelastic changes of lamina propria along with epithelial atrophy, leading to stiffness of oral mucosa [2].

The first case of oral mucosa was seen occurring in Indian in East Africa by Schwartz (1952) as "atropa idiopathica mucosae oris" [3]. The four consecutive histological changes of OSMF was reported by Pindborg and Sirsat (1966) [4]. The irreversible nature of OSMF was described by Seedat and Van Wyle (1968)[5]. They state that OSMF is induced by the habit of chewing betel nuts and the reversal of the disease after the cessation of the habit does not occur.
It has been suggested that consumption of chillies, nutritional deficiency, genetic susceptibility, chewing of areca nut, autoimmunity, altered salivary constituents and collagen disorders may be involved in the pathogenesis of this condition [3]. OSMF is a well-recognized, potentially premalignant condition. Malignant transformation rates as high as $7.6 \%$ have been reported from the Indian subcontinent over a 17 year period [6].

With 75,000-80,000 cases per year, India ranks the highest among all the registries for the highest number of oral cancer cases in the world. Initially these cases were reported in countries like India, Bangladesh and Pakistan, but with the increasing amount of immigration, it is now prevalent in the weatern countries as well [711]. Since 1980, there has been vigorous advertising of products like gutka and pan masala and sudden increase in the number of factories involved. One of the main reasons why the government has not been able to successfully curb this disease is due to the dependency of the livelihood of farmers and others involved in the

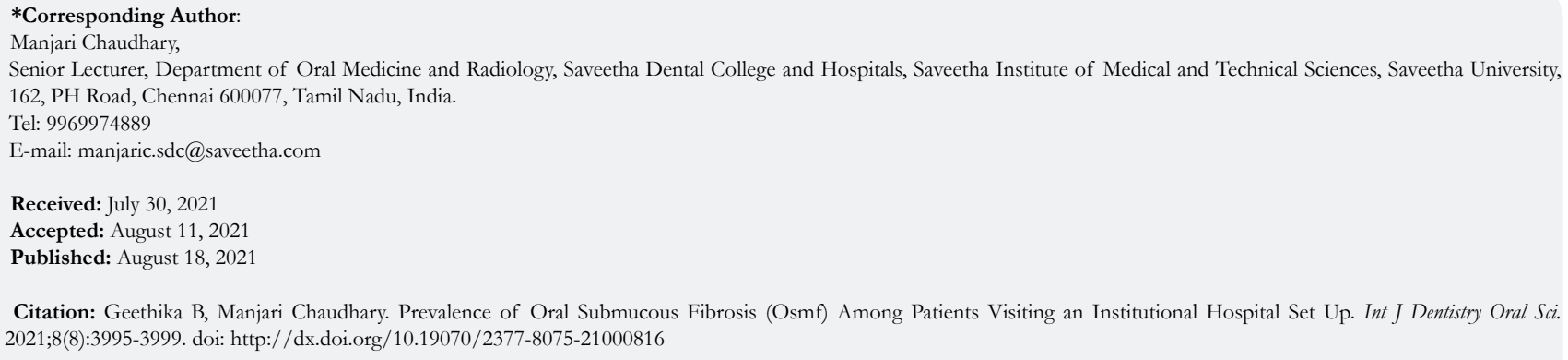

Copyright: Manjari Chaudhary ${ }^{\circ} 2021$. This is an open-access article distributed under the terms of the Creative Commons Attribution License, which permits unrestricted use, distribution and reproduction in any medium, provided the original author and source are credited. 
industry. About $65 \%$ of the total produce of the country's supply of areca nuts is produced from Karnataka. The only possible way to change this would be to educate the farmers about it's harmful effects and encourage them to grow other plants which will also benefit them [12-16].

Previously our team has a rich experience in working on various research projects across multipledisciplines [17-31]. Now the growing trend in this area motivated us to pursue this project. The aim of the present study was to evaluate the prevalence of OSMF among the population visiting an institutional hospital set up.

\section{Materials and Methods}

\section{Study Setting:}

The present retrospective study was carried out in an institutional setting study with an advantage of a wide range of data available and disadvantage being the assessment of single location only. It was conducted to correlate age and OSMF among the male population visiting Saveetha Dental College from June 2019 to March 2020. Ethical clearance for this study was obtained from the Institutional Ethical Committee with the ethical approval number being SDC/SIHEC/2020/DIASDATA/0619-0320. The population included in the study were 145 patients who were diagnosed to have OSMF by the Oral Medicine and Radiology Department. A signed consent was taken from the patients who were included in the study. Two examiners were involved in the study.

\section{Study design:}

The study was designed based on the set inclusion criteria of patients from the oral medicine department who were diagnosed with OSMF. Patients were divided into four groups according to severity, following the criteria from a study done by Ranganathan et al[(32)]. The criteria taken was mouth opening as follows:

Grade I: Only symptoms, with no demonstrable restriction in mouth opening

Grade II: Limited mouth opening. $20 \mathrm{~mm}$ and above

Grade III: Mouth opening less than $20 \mathrm{~mm}$.

Grade IV: OSMF advanced with limited mouth opening. Precan- cerous or cancerous changes seen throughout the mucosa. Cases which did not fall under this inclusion criteria were excluded from the study.

\section{Sampling:}

The study was based on non-probability convenience sampling. To minimize the sampling bias, all the case sheets of patients with OSMF were reviewed and included.

\section{Data Collection and Tabulation:}

It is a retrospective study where the data was collected by reviewing the case records of the patients visiting the Oral medicine and Radiology department of a private dental college from June to March. A total of 100 case sheets were reviewed. Cross verification of the data was done by a reviewer. The collected data was tabulated based on the following parameters: Patients detailsName, Age, Gender, Patient identification number and if the patient was diagnosed with OSMF or not. The age of the patients was categorised for convenience purposes into the following: 20 29 years, 30-39 years, $40-49$ years, 50-59 years and 60-69 years.

\section{Statistical Analysis:}

The data were entered and analysed using Statistical Package for the Social Sciences Software (SPSS) by IBM Version 20.0. Descriptive Statistics (eg. frequencies and percentages) were calculated to explore the general features of the data. Independent variables were age and gender and the dependent variable was OSMF.

\section{Results \& Discussion}

A total of 100 subjects participated in the study of which $93.4 \%$ were males and $6.6 \%$ were females [Table 1]. Grade I OSMF was the most $(67.0 \%)$ prevalent among the population, followed by grade II $(22.0 \%)$, grade III $(7.0 \%)$. The least prevalent was grade IV OSMF [Figure 1]. Grade I OSMF was the most prevalent among all the age groups (20-29 years,30-39 years- 21 ; 40-49 years-14; 5059 years-8; 60-69 years-4)[Figure 2]. The age groups which show a high percentage of prevalence $(25.5 \%)$ of OSMF are $20-29$ years

Table 1. This table shows the prevalence of different grades of OSMF with relation to age and gender.

\begin{tabular}{|c|c|c|c|c|c|c|c|c|}
\hline \multirow{2}{*}{ Variable } & \multicolumn{4}{|c|}{ Grade (\%) } & & \multicolumn{2}{c|}{ Statistical values } \\
\cline { 2 - 9 } & & II & III & IV & Total(\%) & $\begin{array}{c}\text { Pearson } \\
\text { chi-square } \\
\text { value }\end{array}$ & df & p-value \\
\hline Age & & & & & & & & \\
\hline $\mathbf{2 0 - 2 9}$ years & $30.90 \%$ & $20.80 \%$ & $10.00 \%$ & $0.00 \%$ & $25.50 \%$ & & & \\
\hline $\mathbf{3 0 - 3 9}$ years & $30.90 \%$ & $12.50 \%$ & $10.00 \%$ & $0.00 \%$ & $23.60 \%$ & & & \\
\hline $\mathbf{4 0 - 4 9}$ years & $20.60 \%$ & $37.50 \%$ & $10.00 \%$ & $75.00 \%$ & $25.50 \%$ & 26.781 & 12 & $0.008^{*}$ \\
\hline $\mathbf{5 0 - 5 9}$ years & $11.80 \%$ & $25.00 \%$ & $40.00 \%$ & $25.00 \%$ & $17.90 \%$ & & & \\
\hline $\mathbf{6 0 - 6 9}$ years & $5.90 \%$ & $4.20 \%$ & $30.00 \%$ & $0.00 \%$ & $7.50 \%$ & & & \\
\hline Gender & & & & & & & & \\
\hline Male & $66.70 \%$ & $19.20 \%$ & $10.10 \%$ & $4.00 \%$ & $100.00 \%$ & 10.348 & 3 & $0.016^{*}$ \\
\hline Female & $28.60 \%$ & $71.40 \%$ & $0.00 \%$ & $0.00 \%$ & $100.00 \%$ & & & \\
\hline
\end{tabular}

*(Since the $\mathrm{p}$ value is lesser than our chosen significance level $(\alpha=0.05)$, it is statistically significant). 
Figure 1: This frequency distribution graph shows prevalence of different grades of OSMF. $\mathrm{X}$ axis is the grade of OSMF and Y axis represents the percentage of patients with OSMF. Grade I (Green); Grade II(Yellow); Grade III(Pink); Grade IV(Red). It can be seen that the highest percentage of prevalence is seen with Grade I OSMF $(67.00 \%)$.

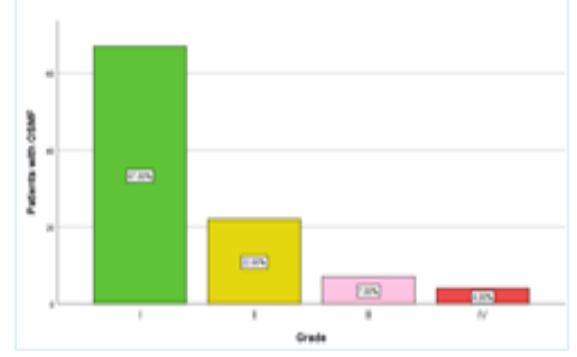

Figure 2: This bar graph shows the association between age and different grades of OSMF. $\mathrm{X}$ axis is the grade of Age and $\mathrm{Y}$ axis represents the number of patients with OSMF. Grade I(Green); Grade II(Yellow);Grade III(Pink); Grade IV(Red). Pearson chi-square test, pvalue: $0.008<0.01$. It can be seen that Grade I OSMF is the most prevalent $(20-29$ years, $30-39$ years- $21 ; 40-49$ years-14; 50-59 years-8; 60-69 years-4) among all the age groups and this association shows a high statistical significance.

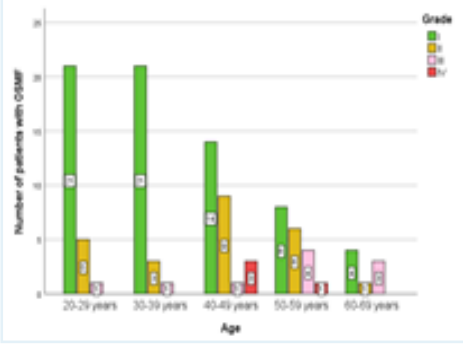

Figure 3: This bar graph shows the association between gender and different grades of OSMF. $\mathrm{X}$ axis is the grade of gender and $\mathrm{Y}$ axis represents the number of patients with OSMF. Grade I(Green); Grade II(Yellow);Grade III(Pink); Grade IV(Red). Pearson chi-square test, p-value:0.016<0.05. It can be seen that the Grade- I,III,IV of OSMF are the most prevalent $(66.7 \%, 10.1 \%, 4.0 \%$ respectively) among males and Grade II is more prevalent (71.4\%) among females and this association is statistically significant.

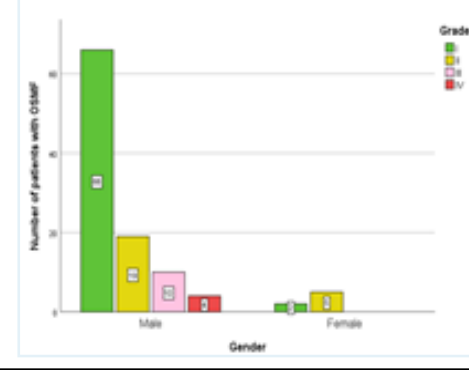

and 40-49 years. Chi-square analysis was performed and it can be seen that there is a high statistical significance between the age and the grade of OSMF (Pearson chi-square test, p-value: $0.008<0.01)$ [Table 1]. It can be seen that the Grade- I,III,IV of OSMF are the most prevalent $(66.7 \%, 10.1 \%, 4.0 \%$ respectively) among males and Grade II is more prevalent (71.4\%) among females and this association is statistically significant (Pearson chisquare test, p-value:0.016<0.05) [Table 1] [Figure 3].

There is compelling evidence that the habit of chewing areca nuts is associated with OSMF and is predominantly seen in the Indian subcontinent [33-36]. The alkaloid present in areca nut- arecoline, is converted into arecadaine which stimulates fibroelastic activity in oral mucosa resulting in excessive collagen which is seen in OSMF [37-39].

From our results we can observe that Grade I OSMF is the most prevalent among the population, across all the age groups. This finding is similar to the observations by Nigam et al.,[40]. Studies by Srivatsava et al.,[41] and Bajoria et al.,[42] shows that Grade II OSMF was more predominant which is contradictory to our study.

In this retrospective study there were 100 subjects who were diag- nosed clinically for having OSMF. Although OSMF affects both sexes, a clear male predominance was seen in our study (93.4\%). This observation is similar to the findings of studies by Ali et al [(43)], Ahmad et al.,[44], Wahi et al.,[45] and Tang et al.,[46]. Certain studies by Pindborg et al.,[47] and Gupta et al.,[48] have shown that there is a female predilection. Certain other studies by Hosein et al.,[49] and Bajoria et al.,[42] have shown that there was no significant association between age, gender and the OSMF grading.

It is observed in our study that the age groups which show a high percentage of prevalence $(25.5 \%)$ of OSMF are $20-29$ years and 40-49 years. There is wide variation in age as reported by other authors which include Pinborg et al[(50)], who stated that the average age of a patients who are diagnosed with OSMF ranges from 40-49 years, Babu et al.,[51] and Trivedy et al.,[52] reported 23\% between 14-19 year olds. Other populations have reported younger populations ranging from 20-30 years [32, 40, 52]. Another study by Jha et al.,[53] shows similar results where a greater fraction of patients were seen in the 21-30 and 31-40 years group. The easy availability and promotions of the areca nut products specially gutkha and pan masala outside the schools colleges and social places has led to the occurrence of OSMF to a greater extent among the younger population. Our institution is passionate 
about high quality evidence based research and has excelled in various fields [54-64]. We hope this study adds to this rich legacy.

Limitations of the present study could be the sample size and geographical isolation. Future studies with more number of participants and studies involving different factors could be conducted.

\section{Conclusion}

Within the limits of the study, it can be concluded that OSMF was more prevalent among males. It can be seen that the Grade- I, III, IV of OSMF are the most prevalent among males and Grade II is more prevalent among females. It is the most prevalent among the age group of 20-29 years and 40-49 years; Grade I OSMF was the most prevalent among all the age groups.

\section{References}

[1]. Venugopal A, Uma Maheswari TN. Expression of matrix metalloproteinase-9 in oral potentially malignant disorders: A systematic review. J Oral Maxillofac Pathol. 2016 Sep-Dec;20(3):474-479.Pubmed PMID: 27721614.

[2]. Sirsat SM, Pindborg JJ. Subepithelial changes in oral submucous fibrosis. Acta Pathol. Microbiol. Scand. 1967;70(2):161-73.

[3]. Murti PR, Bhonsle RB, Gupta PC, Daftary DK, Pindborg JJ, Mehta FS. Etiology of oral submucous fibrosis with special reference to the role of areca nut chewing. J. Oral Pathol. Med. 1995 Apr;24(4):145-52.

[4]. Shrikrishna BH, Jyothi AC. Prevalence of Areca Nut Eating Habits and its Association with Oral Submucous Fibrosis in Preuniversity Collegegoing Adolescents of Raichur in Karnataka, India: A Prospective Cross-sectional Survey. Int J Head Neck Surg. 2016;7: 197-203.

[5]. Seedat HA, Van Wyk CW. Submucous fibrosis (SF) in exbetel nut chewers: A report of 14 cases. J. Oral Pathol. Med .1988 May;17(5):226-9.

[6]. Murti PR, Bhonsle RB, Pindborg JJ, Daftary DK, Gupta PC, Mehta FS. Malignant transformation rate in oral submucous fibrosis over a 17 -year period. Community Dent Oral Epidemiol. 1985 Dec;13(6):340-1.Pubmed PMID: 3866655.

[7]. Nair U, Bartsch H, Nair J. Alert for an epidemic of oral cancer due to use of the betel quid substitutes gutkha and pan masala: a review of agents and causative mechanisms. Mutagenesis. 2004 Jul;19(4):251-62.Pubmed PMID: 15215323

[8]. Chaitanya NC, Muthukrishnan A, Babu DBG, Kumari CS, Lakshmi MA, Palat G, et al. Role of Vitamin E and Vitamin A in Oral Mucositis Induced by Cancer Chemo/Radiotherapy- A Meta-analysis. J Clin Diagn Res. 2017 May;11(5):ZE06-ZE09.Pubmed PMID: 28658926.

[9]. Subashri A, Maheshwari TN. Knowledge and attitude of oral hygiene practice among dental students. Res J Pharm Technol. 2016;9(11):1840-2.

[10]. Maheswari TNU, Venugopal A, Sureshbabu NM, Ramani P. Salivary micro RNA as a potential biomarker in oral potentially malignant disorders: A systematic review. Ci Ji Yi Xue Za Zhi. 2018 Apr-Jun;30(2):55-60.Pubmed PMID: 29875583.

[11]. Misra SR, Shankar YU, Rastogi V, Maragathavalli G. Metastatic hepatocellular carcinoma in the maxilla and mandible, an extremely rare presentation. Contemp Clin Dent. 2015 Mar;6(Suppl 1):S117-21.

[12]. Steele JC, Clark HJ, Hong CH, Jurge S, Muthukrishnan A, Kerr AR, et al. World Workshop on Oral Medicine VI: an international validation study of clinical competencies for advanced training in oral medicine. Oral Surg Oral Med Oral Pathol Oral Radiol. 2015 Aug;120(2):143-51.e7.Pubmed PMID: 25861956.

[13]. Muthukrishnan A, Warnakulasuriya S. Oral health consequences of smokeless tobacco use. Indian J Med Res. 2018 Jul;148(1):35-40.

[14]. Patil SR, Maragathavalli G, Araki K, Al-Zoubi IA, Sghaireen MG, Gudipaneni RK, et al. Three-rooted mandibular first molars in a Saudi Arabian population: A CBCT study. Pesqui Bras Odontopediatria Clin Integr. 2018 Aug 27;18(1):4133.

[15]. Tilakaratne WM, Klinikowski MF, Saku T, Peters TJ, Warnakulasuriya S. Oral submucous fibrosis: review on aetiology and pathogenesis. Oral Oncol. 2006 Jul 1;42(6):561-8.

[16]. Pai SA. Gutkha banned in Indian states. Lancet Oncol. 2002 Sep 1;3(9):521.

[17]. Jain AR. Prevalence of partial edentulousness and treatment needs in rural population of South India. World J. Dent. 2017 Jun;8(3):213-7.

[18]. Varghese SS, Ramesh A, Veeraiyan DN. Blended Module-Based Teaching in Biostatistics and Research Methodology: A Retrospective Study with Post- graduate Dental Students. J Dent Educ. 2019 Apr;83(4):445-450.Pubmed PMID: 30745352.

[19]. Ashok V, Ganapathy D. A geometrical method to classify face forms. J Oral Biol Craniofac Res. 2019 Jul 1;9(3):232-5.

[20]. Padavala S, Sukumaran G. Molar incisor hypomineralization and its prevalence. Contemp Clin Dent. 2018 Sep;9(Suppl 2):S246-50.

[21]. Ke Y, Al Aboody MS, Alturaiki W, Alsagaby SA, Alfaiz FA, Veeraraghavan VP, et al. Photosynthesized gold nanoparticles from Catharanthus roseus induces caspase-mediated apoptosis in cervical cancer cells (HeLa). Artif Cells Nanomed Biotechnol. 2019 Dec;47(1):1938-1946.Pubmed PMID: 31099261.

[22]. Ezhilarasan D. Oxidative stress is bane in chronic liver diseases: Clinical and experimental perspective. Arab J Gastroenterol. 2018 Jun;19(2):56-64.Pubmed PMID: 29853428.

[23]. Krishnan RP, Ramani P, Sherlin HJ, Sukumaran G, Ramasubramanian A, Jayaraj G, et al. Surgical Specimen Handover from Operation Theater to Laboratory: A Survey. Ann Maxillofac Surg. 2018 Jul-Dec;8(2):234-238. Pubmed PMID: 30693238.

[24]. Ezhilarasan D, Sokal E, Najimi M. Hepatic fibrosis: It is time to go with hepatic stellate cell-specific therapeutic targets. Hepatobiliary Pancreat Dis Int. 2018 Jun;17(3):192-197.Pubmed PMID: 29709350.

[25]. Pandian KS, Krishnan S, Kumar SA. Angular photogrammetric analysis of the soft-tissue facial profile of Indian adults. Indian J Dent Res. 2018 Mar 1;29(2):137-43.

[26]. Ramamurthy JA, Mg V. Comparison of effect of Hiora mouthwash versus Chlorhexidine mouthwash in gingivitis patients: A clinical trial. Asian J Pharm Clin Res. 2018 Jul 7;11(7):84-8.

[27]. Gupta P, Ariga P, Deogade SC. Effect of Monopoly-coating Agent on the Surface Roughness of a Tissue Conditioner Subjected to Cleansing and Disinfection: A Contact Profilometric In vitro Study. Contemp Clin Dent. 2018 Jun;9(Suppl 1):S122-S126.Pubmed PMID: 29962776.

[28]. Vikram NR, Prabhakar R, Kumar SA, Karthikeyan MK, Saravanan R. Ball Headed Mini Implant. J Clin Diagn Res. 2017 Jan;11(1):ZL02-3.

[29]. Paramasivam A, Vijayashree Priyadharsini J, Raghunandhakumar S. N6adenosine methylation $(\mathrm{m} 6 \mathrm{~A})$ : a promising new molecular target in hypertension and cardiovascular diseases. Hypertens Res. 2020 Feb;43(2):153154.Pubmed PMID: 31578458.

[30]. Palati S, Ramani P, Shrelin HJ, Sukumaran G, Ramasubramanian A, Don $\mathrm{KR}$, et al. Knowledge, Attitude and practice survey on the perspective of oral lesions and dental health in geriatric patients residing in old age homes. Indian J Dent Res. 2020 Jan-Feb;31(1):22-25.Pubmed PMID: 32246676.

[31]. Samuel SR, Acharya S, Rao JC. School Interventions-based Prevention of Early-Childhood Caries among 3-5-year-old children from very low socioeconomic status: Two-year randomized trial. J Public Health Dent. 2020 Jan;80(1):51-60.Pubmed PMID: 31710096.

[32]. Kiran Kumar K, Saraswathi TR, Ranganathan K, Uma Devi M, Elizabeth J. Oral submucous fibrosis: a clinico-histopathological study in Chennai. Indian J Dent Res. 2007 Jul-Sep;18(3):106-11.Pubmed PMID: 17687172.

[33]. Rohini S, Kumar VJ. Incidence of dental caries and pericoronitis associated with impacted mandibular third molar-A radiographic study. Res J Pharm Technol. 2017;10(4):1081-4.

[34]. Dharman S, Muthukrishnan A. Oral mucous membrane pemphigoid - Two case reports with varied clinical presentation. J Indian Soc Periodontol. 2016 Nov-Dec;20(6):630-634.Pubmed PMID: 29238145.

[35]. Muthukrishnan A, Bijai Kumar L, Ramalingam G. Medication-related osteonecrosis of the jaw: a dentist's nightmare. BMJ Case Rep. 2016 Apr 6;2016:bcr2016214626.Pubmed PMID: 27053542.

[36]. Subha M, Arvind M. Role of magnetic resonance imaging in evaluation of trigeminal neuralgia with its anatomical correlation. Biomed. pharmacol. J. 2019 Mar 25;12(1):289-96.

[37]. Muthukrishnan A, Kumar LB. Actinic cheilosis: early intervention prevents malignant transformation. Case Reports. 2017 Mar 20;2017:bcr2016218654.

[38]. Choudhury P, Panigrahi RG, Maragathavalli, Panigrahi A, Patra PC. Vanishing roots: first case report of idiopathic multiple cervico-apical external root resorption. J Clin Diagn Res. 2015 Mar;9(3):ZD17-9.Pubmed PMID: 25954713.

[39]. Shukla AK, Lecturer S, Department of oral medicine and Radiology, vananchal dental college and hospital, Garhwa. Co relation of areaca nut / betal nut, tobacco and alcohol consumption with OSMF - a case control study . Int J Med Sci Clin Invent. 2017;4.

[40]. Nigam NK, Aravinda K, Dhillon M, Gupta S, Reddy S, Srinivas Raju M. Prevalence of oral submucous fibrosis among habitual gutkha and areca nut chewers in Moradabad district. J Oral Biol Craniofac Res. 2014 JanApr;4(1):8-13.Pubmed PMID: 25737912.

[41]. Srivastava R, Jyoti B, Pradhan D, Siddiqui Z. Prevalence of oral submucous fibrosis in patients visiting dental OPD of a dental college in Kanpur: A 
demographic study. J Family Med Prim Care. 2019 Aug 28;8(8):2612-2617. Pubmed PMID: 31548942.

[42]. Jha VK, Kandula S, Chinnannavar SN, Rout P, Mishra S, Bajoria AA. Oral submucous fibrosis: Correlation of clinical grading to various habit factors. J. Int. Soc. Prev. Community Dent. 2019 Jul;9(4):363.

[43]. Ali FM, Aher V, Prasant MC, Bhushan P, Mudhol A, Suryavanshi H. Oral submucous fibrosis: Comparing clinical grading with duration and frequency of habit among areca nut and its products chewers. J Cancer Res Ther. 2013 Jul-Sep;9(3):471-6.Pubmed PMID: 24125985.

[44]. Ahmad MS, Ali SA, Ali AS, Chaubey KK. Epidemiological and etiological study of oral submucous fibrosis among gutkha chewers of Patna, Bihar, India. J Indian Soc Pedod Prev Dent. 2006 Jun;24(2):84-9.Pubmed PMID: 16823233.

[45]. Wahi PN, Luthra UK, Kapur VL. Submucous fibrosis of the oral cavity. Histomorphological studies. Br. J. Cancer. 1966 Dec;20(4):676-87.

[46]. Tang JG, Jian XF, Gao ML, Ling TY, Zhang KH. Epidemiological survey of oral submucous fibrosis in Xiangtan City, Hunan Province, China. Community Dent Oral Epidemiol. 1997 Apr;25(2):177-80.Pubmed PMID: 9181294.

[47]. Pindborg JJ, Daftary DK, Mehta FS. A follow-up study of sixty-one oral dysplastic precancerous lesions in Indian villagers. Oral Surg Oral Med Oral Pathol. 1977 Mar;43(3):383-90.Pubmed PMID: 265042.

[48]. Gupta PC, Mehta FS, Daftary DK, Pindborg JJ, Bhonsle RB, Jalnawalla PN, et al. Incidence rates of oral cancer and natural history of oral precancerous lesions in a 10-year follow-up study of Indian villagers. Community Dent Oral Epidemiol. 1980;8(6):287-333.Pubmed PMID: 6937277.

[49]. Hosein M, Mohiuddin S, Fatima N. Association Between Grading of Oral Submucous Fibrosis With Frequency and Consumption of Areca Nut and Its Derivatives in a Wide Age Group: A Multi-centric Cross Sectional Study From Karachi, Pakistan. J Cancer Prev. 2015 Sep;20(3):216-22.Pubmed PMID: 26473161

[50]. Pindborg JJ, Bhonsle RB, Murti PR, Gupta PC, Daftary DK, Mehta FS. Incidence and early forms of oral submucous fibrosis. Oral Surg Oral Med Oral Pathol. 1980 Jul 1;50(1):40-4.

[51]. Chaitanya NC, Muthukrishnan A, Krishnaprasad CMS, Sanjuprasanna G, Pillay P, Mounika B. An Insight and Update on the Analgesic Properties of Vitamin C. J Pharm Bioallied Sci. 2018 Jul-Sep;10(3):119-125.Pubmed PMID: 30237682.

[52]. Mehta FS, Gupta PC, Bhonsle RB, Murti PR, Daftary DK, Pindborg JJ. Detection of oral cancer using basic health workers in an area of high oral cancer incidence in India. Cancer Detect Prev. 1986;9(3-4):219-25.Pubmed PMID: 3742502.

[53]. Jha RN, Kalyani PB, Savarkar SV. Incidence rate of oral submucous fibrosis (OSMF) and its etiology in patients visiting Government Dental College and Hospital, Jamnagar (GDCH, Jamnagar). JIHS. 2014 Jan 1;1:11-5.

[54]. Vijayashree Priyadharsini J. In silico validation of the non-antibiotic drugs acetaminophen and ibuprofen as antibacterial agents against red complex pathogens. J Periodontol. 2019 Dec;90(12):1441-1448.Pubmed PMID: 31257588.

[55]. Pc J, Marimuthu T, Devadoss P, Kumar SM. Prevalence and measurement of anterior loop of the mandibular canal using CBCT: A cross sectional study. Clin Implant Dent Relat Res. 2018 Apr 6;20(4):531-4.

[56]. Ramesh A, Varghese S, Jayakumar ND, Malaiappan S. Comparative estimation of sulfiredoxin levels between chronic periodontitis and healthy patients - A case-control study. J Periodontol. 2018 Oct;89(10):1241-1248.Pubmed PMID: 30044495 .

[57]. Ramadurai N, Gurunathan D, Samuel AV, Subramanian E, Rodrigues SJ. Effectiveness of $2 \%$ Articaine as an anesthetic agent in children: randomized controlled trial. Clin Oral Investig. 2019 Sep;23(9):3543-50.

[58]. Sridharan G, Ramani P, Patankar S, Vijayaraghavan R. Evaluation of salivary metabolomics in oral leukoplakia and oral squamous cell carcinoma. J Oral Pathol Med. 2019 Apr;48(4):299-306.

[59]. Ezhilarasan D, Apoorva VS, Ashok Vardhan N. Syzygium cumini extract induced reactive oxygen species-mediated apoptosis in human oral squamous carcinoma cells. J Oral Pathol Med. 2019 Feb;48(2):115-121.Pubmed PMID: 30451321.

[60]. Mathew MG, Samuel SR, Soni AJ, Roopa KB. Evaluation of adhesion of Streptococcus mutans, plaque accumulation on zirconia and stainless steel crowns, and surrounding gingival inflammation in primary molars: randomized controlled trial. Clin Oral Investig. 2020 Sep;24(9):1-6.Pubmed PMID: 31955271.

[61]. Samuel SR. Can 5-year-olds sensibly self-report the impact of developmental enamel defects on their quality of life? Int J Paediatr Dent. 2021 Mar;31(2):285-286.Pubmed PMID: 32416620.

[62]. R H, Ramani P, Ramanathan A, R JM, S G, Ramasubramanian A, et al. CYP2 C9 polymorphism among patients with oral squamous cell carcinoma and its role in altering the metabolism of benzo[a]pyrene. Oral Surg Oral Med Oral Pathol Oral Radiol. 2020 Sep;130(3):306-312.Pubmed PMID: 32773350 .

[63]. Chandrasekar R, Chandrasekhar S, Sundari KKS, Ravi P. Development and validation of a formula for objective assessment of cervical vertebral bone age. Prog Orthod. 2020 Oct 12;21(1):38.Pubmed PMID: 33043408.

[64]. Vijayashree Priyadharsini J, Smiline Girija AS, Paramasivam A. In silico analysis of virulence genes in an emerging dental pathogen A. baumannii and related species. Arch Oral Biol. 2018 Oct;94:93-98.Pubmed PMID: 30015217. 